\title{
STUDIES ON L-VALINE FERMENTATION PART I. PRODUCTION OF L-VALINE BY AEROBACTER BACTERIA
}

\author{
ZENZIRÔ SUGISAKI \\ Noda Institute for Scientific Research \\ Received for publication, August 17, 1959
}

A marvelous outbreak in the field of the so-called "Amino acid Fermentation" has first been performed by Japanese workers such as $\mathrm{Mr}$. Kinoshita et al. (1) in observations concerning L-glutamic acid fermentation. The basic concept is now successfully extended to microbial methods for the preparation of essential amino acids, for instance, L-lysin (2) and L-tryptophane (3), etc.

Meanwhile, L-valine is reported to be detected in a minute amount inside the cell or in the surrounding medium by many investigators $(7,8,9)$ in detailed studies on biosynthesis, and more recently, Asal et al. (4) and Kinoshita et al. (1) have further pointed out the presence of a trace-amount of valine detectable with other amino acids in the culture medium in case of amino acid fermentation caused by some microbes. However, the production of valine in a high level has never been described, until UDAKA et al. (5) recently reported on the production of L-valine by some microorganisms, especially, Paracolobactrum coliforme, which accumulates 7-8 mg of valine per $\mathrm{ml}$ of broth after 48 hours' incubation by shake culture.

From an independent standpoint of these workers, the present author has undertaken extensive studies on the subject and it has been found that L-valine can be produced by some newly isolated specific strains from carbohydrates and ammonia sources in the culture broth at a high level of 12 $13 \mathrm{mg}$ per $\mathrm{ml}$ of broth. The author thus investigated the possibility of formation of $\mathrm{L}$-valine fermentation.

In practice, it is worthy to take advantage of a method to readily produce an optically active L-valine product, due to the fact that it is still prepared by means of resolution of chemical synthetics, DL-isomers, or the separation from protein hydrolysates.

\section{EXPERIMENTAL}

\section{Isolation and Screening of $\mathrm{L}$-Valine Producing Bacteria}

Isolation of organisms; Performed in the usual manner.

This work was presented at the meeting of the Agricultural Chemical Society of Japan held at Tokyo University on Feb., 28, 1959. 
Screening experiments; The composition of the medium used in the screening test was as follows: $10 \%$ glucose, $1.2 \% \mathrm{NH} \mathrm{Cl}, 0.1 \% \mathrm{KH}_{2} \mathrm{PO}_{4}$, $0.05 \% \mathrm{MgSO}_{4} \cdot 7 \mathrm{H}_{2} \mathrm{O}$. Ten $\mathrm{ml}$ of the medium placed in a test tube $(\mathrm{D}=23 \mathrm{~m} / \mathrm{m})$ was inoculated with one loopful of the organisms from each slant culture, adding $3-4 \% \mathrm{CaCO}_{3}$ sterilized separately, and incubated with shaking culture employing a reciprocal shaker at 350 r.p.m., amplitude of vibration, $2 \mathrm{~cm}$. The amino acids produced in the broth were analysed after three days' culture of bacteria.

Analytical methods; A routine identification and rough quantitative estimation of the amino acids were made by the paper chromatographic procedure carried out in the usual manner. For the screening test, $2 \mu \mathrm{l}$ of the broth was spotted on the filter paper, Toyô No. 50, which was developed with use of n-butanol-acetic acid-water $(4: 1: 1)$ for about eighteen hours at $20^{\circ} \mathrm{C}$. The chromatogram was treated with $0.2 \%$ ninhydrin solution in $96 \%$ ethanol. Rf-value of valine is about 0.50 . Quantitative analysis of L-valine was made by application of the ordinary bioassay technique, using Leuconostoc mesenteroides P-60 or Lactobacillus arabinosus 17-5. Glucose was determined according to the method of Fehling-Lehmann-Schoorl, and ammoniacal nitrogen by Conway's micro diffusion analysis. ${ }^{13)}$ Turbidity and $\mathrm{pH}$ were measured by a Hitachi Photoelectric Spectrophotometer and Beckman type glass electrode $\mathrm{pH}$-meter respectively. Numerous known and isolated bacteria were tested in the screening experiments. The valine spot on paper chromatogram was detected in the usual manner which is described above. As already cited by some other investigators, it was frequently found that a considerable number of bacteria produce alanine, glutamic acid, or aspartic acid, and also that a trace amount of valine producing microorganisms are widely distributed not only in some genera of Enterobacteriaceae but in other kinds of bacteria and furthermore, in some genera of yeasts, not to mention Escherichia coli, Neurospora crassa, Sacharomyces cerevisiae and Torulopsis utilis in agreement with earlier observations $(7,8,9)$. However, in most of these cases valine was rathermore a by-product accompanied with other main amino acid products. The amount of valine produced by comparatively specific bacteria ranged from $1-3 \mathrm{mg}$ of $\mathrm{ml}$ broth in many strains, and in a few strains far more than $5 \mathrm{mg}$. However, some specific strains which solely accumulate L-valine in a high level could rarely be found, and most of them belong to the Coli-Aerogenes group. Thus the highest level of L-valine accumulation, $8-12 \mathrm{mg}$ per $\mathrm{ml}$ broth, was shown by some of the newly isolated strains, falling into the head of Genus Aerobacter; NISR-B-151, NISR-B-801 and that group.

\section{Identification of $\mathrm{L}$-Valine producing Bacteria}

Methods: Diagnostic tests were carried out according to "Manual of microbiological methods" by the Society of American Bacteriologists (1957), and referred to "Hand-book of Practical Bacteriology" by Mackie \& 
MacCartney 9th Ed., E. \& S. Living Stone, Ltd., Edinburgh and London (1956), "An Introduction to Laboratory Technique in Bacteriology" by Max Levine 3rd Ed., McMillan Co., New York (1954), and "Saikin-Gaku Jisshu Teiyo" by the Institute for Infectious Diseases, Univ. of Tokyo. In the present table, a detailed description of two strains of the specific bacteria is presented.

Table 1. Characters of L-Valine producing Bacteria

\begin{tabular}{|c|c|c|}
\hline $\begin{array}{l}\text { Strains } \\
\text { Description }\end{array}$ & NISR-B-151 & NISR-B-801 \\
\hline $\begin{array}{l}\text { I. Morphological: } \\
\text { vegetative cells }\end{array}$ & $\begin{array}{l}\text { Rods, } 0.5 \sim 1.0 \times 1.0 \sim 2.0 \mu \text {, } \\
\text { single. } \\
\text { gram negative. } \\
\text { motile with peritrichous } \\
\text { flagella. } \\
\text { not encapsulated. } \\
\text { none. }\end{array}$ & $\begin{array}{l}\text { Rods } 0.5 \sim 0.8 \times 1.0 \sim 2.0 \mu, \\
\text { single. } \\
\text { gram negative. } \\
\text { non-motile. } \\
\text { capsulated. } \\
\text { none. }\end{array}$ \\
\hline \multicolumn{3}{|l|}{ II. Cultural: } \\
\hline 1. Agar colonies & $\begin{array}{l}\text { circular, frequently Rhi- } \\
\text { zoid, thin, opaque with } \\
\text { white-center (umbonate), } \\
\text { entire. }\end{array}$ & $\begin{array}{l}\text { thick, white, raised, moist, } \\
\text { smooth, entire, mucoid. }\end{array}$ \\
\hline 2. Agar stroke & $\begin{array}{l}\text { growth moderate, filiform, } \\
\text { glistening, porcelain white. }\end{array}$ & $\begin{array}{l}\text { abundant growth, thick, } \\
\text { white, moist, glistening, } \\
\text { spreading growth. }\end{array}$ \\
\hline 3. Gelatin colonies $\left(20^{\circ}\right)$ & $\begin{array}{l}\text { thin, smooth, circular, } \\
\text { bluish, translucent. }\end{array}$ & $\begin{array}{l}\text { thick, white, moist, smooth, } \\
\text { entire. }\end{array}$ \\
\hline 4. Gelatin stab & $\begin{array}{l}\text { slow liquefaction; filiform, } \\
\text { napiform to infundibuli- } \\
\text { form. }\end{array}$ & $\begin{array}{l}\text { no liquefaction; thick, } \\
\text { spreading, white, opaque } \\
\text { surface growth. }\end{array}$ \\
\hline 5. Nutrient Broth & $\begin{array}{l}\text { turbid, thin pellicle, fecal } \\
\text { odor not produced. }\end{array}$ & $\begin{array}{l}\text { Turbid, pellicle, abundant } \\
\text { sediment. }\end{array}$ \\
\hline 6. Opt. Temperature & $30^{\circ} \sim 38^{\circ} \mathrm{C}$ & $30^{\circ} \mathrm{C}$ \\
\hline 7. Opt. $\mathrm{pH}$ & $\begin{array}{l}\text { growth } 6 \sim 42^{\circ} \mathrm{C} \text {, thermal } \mathrm{d} \\
\text { Gas not produced in Eijkm } \\
45^{\circ} \sim 46^{\circ} \mathrm{C} \text { (both). } \\
\text { pH } 6.0-6.8 \text { (limit } 4.6 \sim 9.0)\end{array}$ & $\begin{array}{l}\text { leath point, } 65^{\circ} \times 10 \mathrm{~min} \text {. } \\
\text { han test carried out at } \\
(\mathrm{pH} 6.0-6.8 \text { (limit } 4.4 \sim 9.0)\end{array}$ \\
\hline 8. Relation to free- $\mathrm{O}_{2}$ & $\begin{array}{l}\text { Aerobic, facultatively an- } \\
\text { aerobic. }\end{array}$ & $\begin{array}{l}\text { Aerobic, facultatively an- } \\
\text { aerobic. }\end{array}$ \\
\hline 9. Chromogenesis (Potato) & $\begin{array}{l}\text { brownish, moist, glisten- } \\
\text { ing growth. }\end{array}$ & $\begin{array}{l}\text { thick, yellowish brown, } \\
\text { spreading \& glistening } \\
\text { growth. }\end{array}$ \\
\hline \multicolumn{3}{|l|}{ III. Physiological: } \\
\hline 1. Litmus milk & $\begin{array}{l}\text { acid; coagulation; gas; } \\
\text { rapid peptonization. }\end{array}$ & $\begin{array}{l}\text { acid with coagulation; no } \\
\text { peptonization. }\end{array}$ \\
\hline
\end{tabular}




\begin{tabular}{|c|c|c|}
\hline $\begin{array}{l}\text { 2. Action on Nitrate } \\
\left(\mathrm{NO}_{3}^{\prime} \rightarrow \mathrm{NO}_{2}^{\prime}\right)\end{array}$ & + & + \\
\hline 3. Indole production & - & - \\
\hline 4. M. R. Test & - & - \\
\hline 5. V.P. Reaction & + & + (weak) \\
\hline 6. Utilization of Citrate & + & + \\
\hline 7. $\mathrm{H}_{2} \mathrm{~S}$ produdtion & + & - \\
\hline $\begin{array}{l}\text { 8. Gas Ratio fermented with } \\
\text { Glucose }\end{array}$ & $\mathrm{CO}_{2}: \mathrm{H}_{2} \fallingdotseq 2: 1$ & $\mathrm{CO}_{2}: \mathrm{H}_{2} \geq 2: 1$ \\
\hline 9. Utilization of $\mathrm{NH}_{4}{ }^{\prime}$-salt & + & + \\
\hline 10. Utilization of Uric acid & + & + \\
\hline $\begin{array}{l}\text { Hydrolysis of } \\
\text { Na-hippurate }\end{array}$ & - & + \\
\hline $\begin{array}{l}\text { 12. Decomposition of } \\
\text { Na-Alginate }\end{array}$ & $+($ Acid $)$ & - \\
\hline 13. Reduction of Indicator & litmus $(+), \mathrm{NR}(+)$ & litmus $(+), \mathrm{NR}(+)$ \\
\hline 14. $\mathrm{NH}_{3}$ production & + & + \\
\hline 15. Catalase & + & + \\
\hline Urease & \pm & + \\
\hline $\begin{array}{l}\text { 17. Fermentation of Sugars } \\
\text { (cf: Table 2) }\end{array}$ & & \\
\hline Glycerol & A- & AG \\
\hline Glucose & AG & AG \\
\hline Lactose & $\mathrm{AG}$ & AG \\
\hline
\end{tabular}

A: Acid, G: Gas, Media; similar to that in Table 2.

On the basis of these data, comparative studies were conducted in accordance with the descriptions of BergeY's manual, 6th and 7th Ed.

1. Decision of Family: Both strains are Gram-negative, aerobic or facultatively anaerobic, nonsporulating, small rods, fermenting glucose with production of acid and gas, and produce nitrites from nitrates characteristically. The strains therefore fall under the head of Family Enterobacteriaceae.

2. Decision of Tribe: Strains ferment lactose, producing acid and gas, but do not produce prodigiosin and protopectinase; therefore they should be classified as Tribe Escherichieae.

3. Decision of Genus: From the so-called IMViC test $(--++)$ and gas ratio in glucose decomposition, they should fall under the category of Genus Aerobacter.

4. Decision of Species: Though strain NISR-B-151 is considered to be $A$. cloacae, since this strain ferments glycerol with the production of acid and no visible gas and liquefies gelatin; but it is differs in some points regarding characters in type culture-production of hydrogen sulfide, decomposition of sodium alginate, and fermentation of some sugars-so that it is recognized to be $A$. cloacae var sp. 
Another strain NISR-B-801, ferments glycerol, producing acid and gas, but does not liquefy gelatin, other properties also being similar to that of the type culture. Thus this strain is identified as one of the typical A. aerogenes.

In the above strains, it is an exceedingly specific character to exhibit the strong activity of L-valine accumulation which is more markable than common Coli-Aerogenes bacteria, in culture media from carbohydrates and nitrogen sources by shake culture.

\section{L-Valine Production from several kinds of Carbohydrates and Nitrogen sources by Aerobacter.}

By shake culture, both strains produce valine not only from glucose and ammonium chloride but also, more or less, from several kinds of carbohydrates and ammonium sources, as shown qualitatively in Tables 2 and 3. In all of the author's experiments, methods similar to those described before were applied except in case of media noted in each table.

1. L-Valine production from several kinds of Carbohydrates

Each media contained $2 \%$ carbohydrates and $0.7 \% \mathrm{NH}_{4} \mathrm{Cl}$ in stead of $10 \%$ glucose and $1.2 \% \mathrm{NH}_{4} \mathrm{Cl}$, respectively.

It was observed that $\mathrm{L}$-valine is formed from both hexose and most of the assimilative carbohydrates as shown in Table 2-from pentoses, oligosaccharides, polyols and polysaccharides.

\section{Utilization of several kinds of Nitrogen Sources}

Concentration of each nitrogen source was $0.3 \%$ as nitrogen, corresponding to ca $1.2 \% \mathrm{NH}_{4} \mathrm{Cl}$.

From Table 3 it is evident that both strains may be able to utilize several kinds of inorganic and organic nitrogen sources, except nitrites, accompanied with the formation of valine. Further, from some other quantitative experimental results it was found that ammonium salts of strong acids, such as $\mathrm{NH}_{4} \mathrm{Cl},\left(\mathrm{NH}_{4}\right)_{2} \mathrm{SO}_{4}, \mathrm{NH}_{4} \mathrm{NO}_{3}$, etc., are suitable nitrogen sources for this fermentation.

\section{Progressive-Fermentation of Aerobacter}

One of the specific strains, $A$. cloacae var. sp. NISR-B-151, showed a high level of L-valine accumulation and an example of the progressive production of $\mathrm{L}$-valine by the strain is shown in Fig. 1 .

Medium : $10 \%$ glucose, $1.2 \% \mathrm{NH}_{4} \mathrm{Cl}, 0.15 \% \mathrm{KH}_{2} \mathrm{PO}_{4}, 0.03 \% \mathrm{MgSO}_{4} \cdot 7 \mathrm{H}_{2} \mathrm{O}$, $10 \mathrm{ppm} \mathrm{MnSO}_{4} \cdot \mathrm{nH}_{2} \mathrm{O} ; 3 \% \mathrm{CaCO}_{3}$ (sterilized separately).

Incubation: $50 \mathrm{ml}$ of the medium dispensed in a $500 \mathrm{ml}$ shake flask was inoculated with 2 loopfuls from the slant culture of $A$. cloacae var sp. NISR-B-151, and reciprocal shake culture (136 r.p.m.) was carried out at $30 \pm 2^{\circ} \mathrm{C}$. Assay methods are similar to that described in the screening experiment. 
Table 2. Fermentation of Sugars \& L-Val. production

\begin{tabular}{|c|c|c|c|c|c|c|c|}
\hline \multirow{2}{*}{\multicolumn{2}{|c|}{ 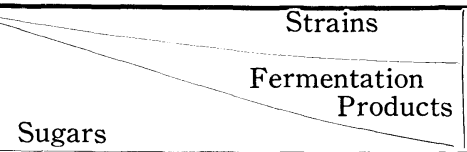 }} & \multicolumn{3}{|c|}{ NISR-B-151 } & \multicolumn{3}{|c|}{ NISR-B-801 } \\
\hline & & \multirow{2}{*}{$\begin{array}{l}\text { A } \\
+\end{array}$} & \multirow{2}{*}{$\begin{array}{l}\mathrm{G} \\
+\end{array}$} & \multirow{2}{*}{$\frac{\text { L-Val. }}{+}$} & \multirow{2}{*}{$\begin{array}{l}\mathrm{A} \\
+\end{array}$} & \multirow{2}{*}{$\begin{array}{l}\text { G } \\
+\end{array}$} & \multirow{2}{*}{$\frac{\text { L-Val. }}{ \pm}$} \\
\hline 1 & Arabinose & & & & & & \\
\hline 2 & Rhamnose & + & + & \pm & + & + & - \\
\hline 3 & Xylose & + & + & $H$ & + & + & $H$ \\
\hline 4 & Glucose & + & + & H & + & + & $H$ \\
\hline 5 & Fructose & + & + & H & + & + & $H$ \\
\hline 6 & Galactose & + & + & $H$ & + & + & \pm \\
\hline 7 & Mannose & + & + & H & + & + & $H$ \\
\hline 8 & Lactose & + & + & - & + & + & + \\
\hline 9 & Sucrose & + & + & - & + & + & + \\
\hline 10 & Maltose & + & + & + & + & + & + \\
\hline 11 & Trehalose & + & + & $H$ & + & + & \pm \\
\hline 12 & Cellobiose & + & + & $H$ & + & + & \pm \\
\hline 13 & Raffinose & - & - & - & + & + & + \\
\hline 14 & Starch & - & - & - & + & + & - \\
\hline 15 & Inuline & - & - & - & - & - & - \\
\hline 16 & Dextrine & - & - & - & \pm & - & - \\
\hline 17 & Glycerol & \pm & - & - & + & + & - \\
\hline 18 & Arabitol & - & - & - & + & + & H \\
\hline 19 & Mannitol & + & + & - & + & + & + \\
\hline 20 & Sorbitol & + & + & $H$ & + & + & H \\
\hline 21 & Dulcitol & - & - & - & - & - & - \\
\hline 22 & Inositol & - & - & - & + & + & + \\
\hline 23 & Salicin & \pm & + & \pm & + & + & - \\
\hline 24 & Aesculin & + & + & - & + & + & + \\
\hline 25 & Arbutin & + & + & - & + & + & - \\
\hline 26 & $\alpha$-Methyl-glucoside & + & + & - & + & + & \pm \\
\hline
\end{tabular}

A: Acid, G: Gas.

$1 \%$ Sugar solution containing pepton-water and the Ayer-Rupp-Johnson, artificial medium. L-Val. production Media: Sugar $2 \%, \quad \mathrm{NH}_{4} \mathrm{Cl} 0.7 \%, \mathrm{KH}_{2} \mathrm{PO}_{4} 0.1 \%$, $\mathrm{MgSO}_{4} \cdot 7 \mathrm{H}_{2} \mathrm{O} 0.05 \%, \mathrm{CaCO}_{3} 1 \%$.

After 72 hours' incubation $12 \mathrm{mg}$ of L-valine was produced from $92 \mathrm{mg}$ of consumed glucose per $\mathrm{ml}$ of broth, corresponding to $20 \%$ of theoretical yield, as mole by mole ratio from consumed glucose many be formed. Similar results were also observed in cases of A. aerogenes NISR-B-801. 
Isolation and Identification of $\mathrm{L}$-Valine Produced in the Culture Broth Isolation of Valine: In order to isolate valine produced in the culture broth, it is a more practical procedure to advantageously employ Ion Exchanger Method (Displacement chromatography using a strongly acidic cation exchange resin) reported by PARTRIDGe and BRIMely (6) than copper-salt separation or butanol-extraction.

In Fig. 2, the outlines of substantial treatment of the broth and isolation of valine are presented.

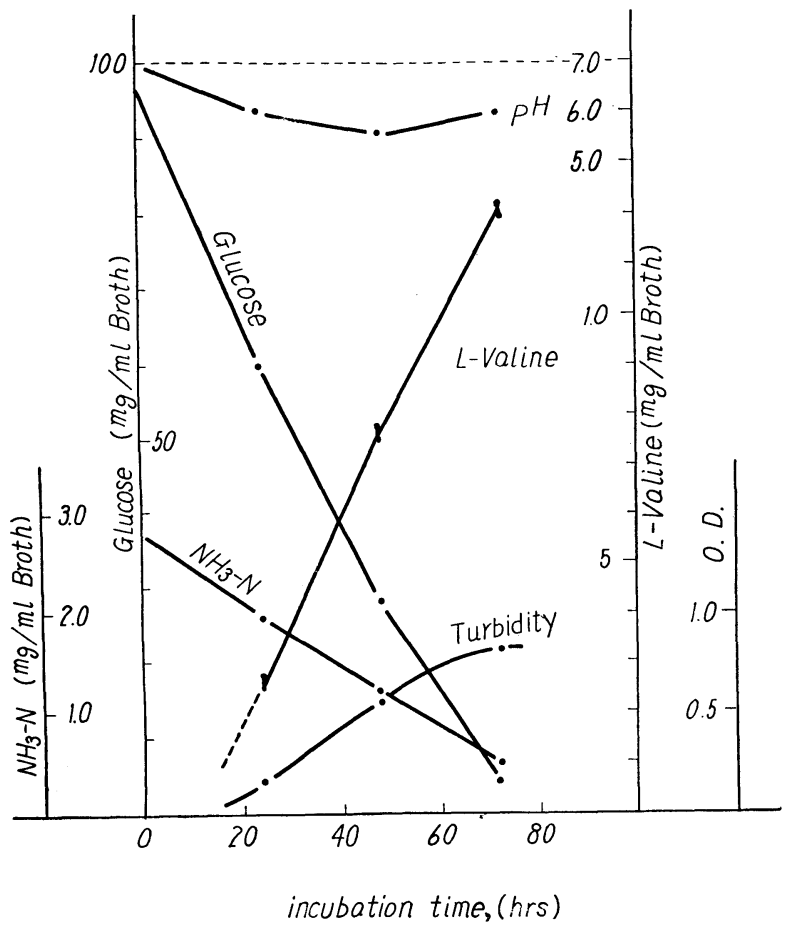

Fig. 1 Chemical changes during Fermentation.

Strain: A. cloacae var sp. NISR-B-151.

Medium: $9.6 \%$ glucose, $1.2 \% \quad \mathrm{NH}_{4} \mathrm{Cl}, 0.15 \% \quad \mathrm{KH}_{2} \mathrm{PO}_{4}$, $0.03 \% \mathrm{MgSO}_{4} \cdot 7 \mathrm{H}_{2} \mathrm{O}, 10 \mathrm{ppm} \mathrm{MnSO}_{4} \cdot \mathrm{nH}_{2} \mathrm{O}(\mathrm{pH} 6.6)$

Conditions, noted in the text.

The isolated crystals, magnificient hexagonal flat-plate, were dried up under reduced pressure in a desiccator and further desiccated by Abderhalden's apparatus.

\section{Identification of $\mathrm{L}$-Valine}

Subsequent to these operations, the crystals were then subjected to the following examination, i.e., identification with $\mathrm{L}$-valine, by physical, chemical and biological procedures. 


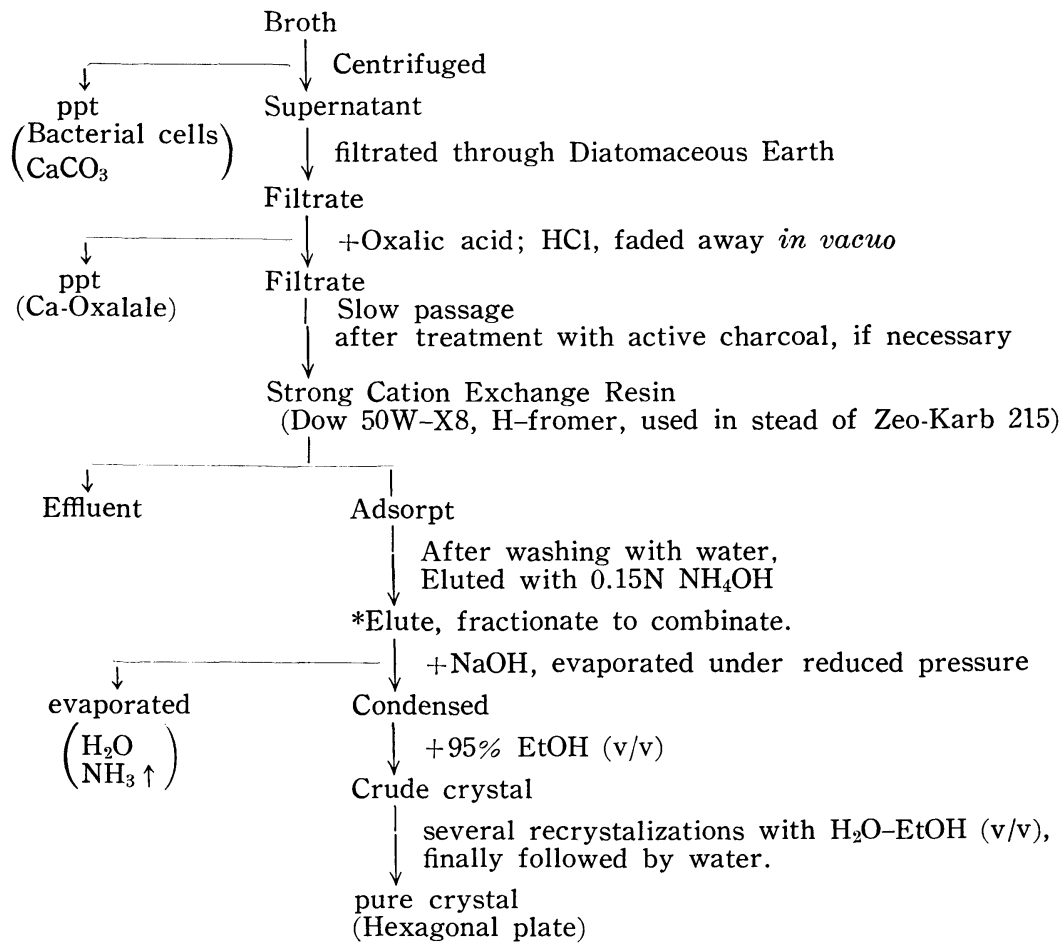

Fig. 2. Isolation of Valine from culture broth.

* Each of these various fraction was tested individually by paper chromato. graphy, and fractions containing valine were combined and evaporated to condensed one under reduced pressure under a weakly basic with driving out ammonia at the same time.

(i) Paper-Partition Chromatography ;

Rf, 0.49 n-butanol-acetic acid-water, 0.81 phenol-water,

(ii) M.P., $315^{\circ}$ (Decomposition; Lit., $315^{\circ}$ )

$147^{\circ}$ as p-Toluensulfonyl derivatives. (auth., $147^{\circ}$; no depression)

(iii) Elementary Analysis ;

$\begin{array}{lccc} & \mathrm{C} & \mathrm{H} & \mathrm{N} \\ \text { Found : } & 51.18 & 9.42 & 11.80 \\ \text { Calc'd. for } \mathrm{C}_{5} \mathrm{H}_{11} \mathrm{O}_{2} \mathrm{~N}: & 51.26 & 9.45 & 11.96\end{array}$

(iv) $[\alpha]_{\mathrm{D}}^{20}=+28.4^{\circ}\left(6 \mathrm{~N} \mathrm{HCl}, \mathrm{C} 3.4\right.$; Lit $\left.28.8^{\circ}\right)$

(v) Bioassay by Lact. arabinosus 17-5 and Leuc. Mesenteroides P-60 showed to be L-valine.

(vi) Infrared Spectra; 


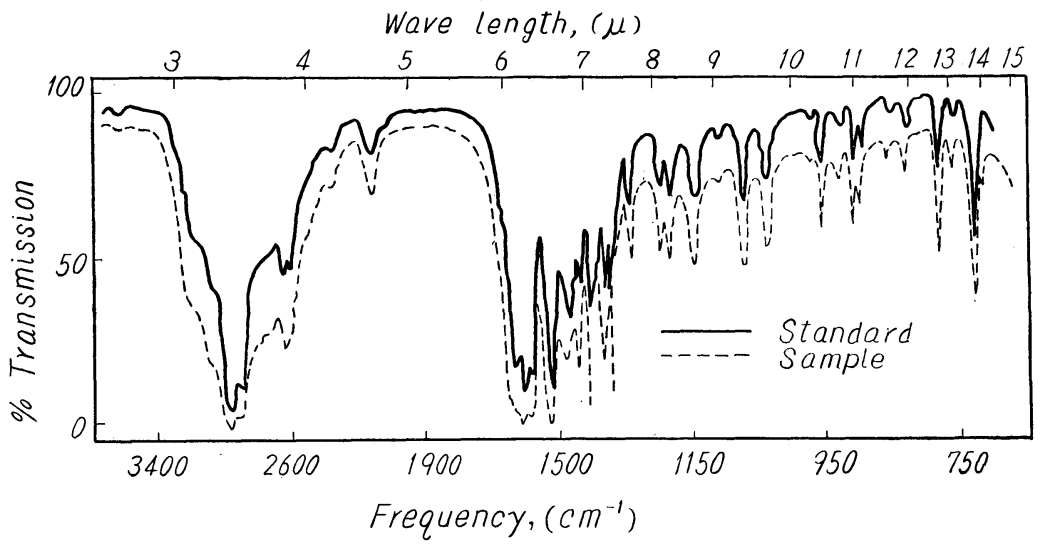

Table 3 Utilization of $\mathrm{NH}_{4}$-salts \& $\mathrm{L}-\mathrm{Val}$. production

\begin{tabular}{|c|c|c|c|c|c|}
\hline & \multirow{2}{*}{$\mathrm{N}$-sources } & \multicolumn{2}{|c|}{ NISR-B-151 } & \multicolumn{2}{|c|}{ NISR-B-801 } \\
\hline & & Growth & L. Val. & Growth & L-Val. \\
\hline 1 & $\mathrm{NH}_{4} \mathrm{Cl}$ & 世 & H & H & m \\
\hline 2 & $\left(\mathrm{NH}_{4}\right)_{2} \mathrm{SO}_{4}$ & H & H & H & $H$ \\
\hline 3 & $\mathrm{NH}_{4} \cdot \mathrm{H}_{2} \mathrm{PO}_{4}$ & $H$ & \pm & $H$ & + \\
\hline 4 & $\left(\mathrm{NH}_{4}\right)_{2} \mathrm{HPO}_{4}$ & $H$ & + & + & + \\
\hline 5 & $\mathrm{NH}_{4} \cdot \mathrm{NO}_{3}$ & H & H & H & H \\
\hline 6 & $\mathrm{~K} \cdot \mathrm{NO}_{3}$ & H & + & H & \pm \\
\hline 7 & $\mathrm{Na} \cdot \mathrm{NO}_{3}$ & H & H & H & \pm \\
\hline 8 & $\mathrm{~K} \cdot \mathrm{NO}_{2}$ & - & - & - & - \\
\hline 9 & $\mathrm{Na} \cdot \mathrm{NO}_{2}$ & - & - & - & - \\
\hline 10 & $\mathrm{NH}_{4}$-Acetate & + & + & H & H \\
\hline 11 & $\left(\mathrm{NH}_{4}\right)_{2}-$ Tartarate & - & - & $H$ & \pm \\
\hline 12 & $\mathrm{NH}_{4}$-Lactate & + & H & \# & $H$ \\
\hline 13 & Urea & \pm & - & H & + \\
\hline
\end{tabular}

Med.: Glucose $10 \%, \quad \mathrm{NH}_{4}$-salts $0.3 \% \mathrm{~N}, \quad \mathrm{KH}_{2} \mathrm{PO}_{4} 0.1 \%, \quad \mathrm{MgSO}_{4} \cdot 7 \mathrm{H}_{2} \mathrm{O} 0.05 \%$; $\mathrm{CaCO}_{3} 3 \%$

\section{DISCUSSION}

It has been observed that the accumulation of L-valine by the specific strains occurs when the organisms are in growth, and that a sole amino acid or only a few kinds of amino acids are produced. Therefore the production of valine may be easily accounted in the absence of autolysis, in which case various kinds of amino acids are expected to be detectable. 
Recently, in detailed studies of valine metabolism performed by many workers $(7,8,9)$, it was recognized that $\alpha$-acetolactate is the first precursor in L-valine biosynthesis. Thence, together with the early informations $(10,11,12,14)$, it was clarified that the pathway of valine biosynthesis appears to be shown in the presented shema diagramed with a solid line in Fig. 3, though some difference in detail was observed between yeast $(7)$ and E. $\operatorname{coli}(\mathbf{8})$ or Neurospora crassa $(9)$.

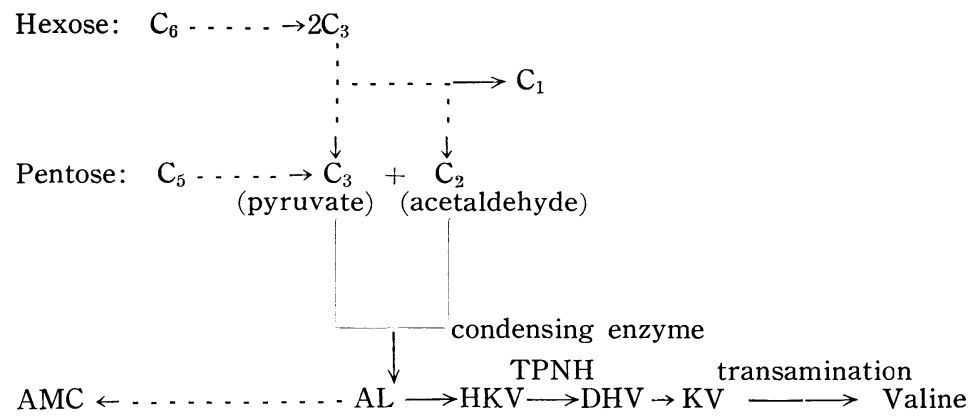

Fig. 3. Known postulated Mechanism of Valine Biosynthesis $(\longrightarrow)$

Note of abbreviations:

AL; $\alpha$-acetolactate, $\mathrm{HKV} ; \alpha$-keto- $\beta$-hydroxy isovaleric acid, the so-called

Hydroxy-ketovaline. DHV; $\alpha, \beta$-dihydroxy isovaleric acid, the so-called

Di-hydroxy valine, AMC; Acetyl-methly-carbinol.

From the point of view concerning intermediates and chemical changes occurring in this fermentation, similar suggestions have been presented; (1) the so-called $\mathrm{C}_{5}$-precursors are perceptible in broth, and (2) a considerable amounts of pyruvate and acetaldehyde are detectable in culture media in an early stage of fermentation, and further, (3) L-valine is formed from both hexoses and pentoses, especially readily from fructose and xylose. Thence it may be preseumed that the dotted line process and the known successive pathway shown by the solid line should be existential in this fermentation.

Meanwhile, in the course of screening experiments, the author has always held the opinion that L-valine production specificity is noticeable in those microbes which are aerobic or facultatively anaerobic microorganisms, decomposing glucose with the production of acid and gas, and are characteristically positive in the modificated Voges-Proskauer reaction, provided Barritt's modification is applied to the culture media after addition of hot sulphuric acid and polypepton. In fact, almost all microbes possesing these three properties are able to form valine to a certain extent under similar conditions previously described. Then, it can be properly comprehended, in a broad sense, on the basis of the correspondence between the theory and observations, that the positive reaction in the modificated V-P test is, in general, due to the presence of $\alpha$-acetolactate rather than acetyl-methyl- 
carbinol in this fermentation broth. Hence L-valine producibility is not always a common property solely observed in Enterobacteriaceae. The specific strains which produce a large amount of valine should be endowed with a strongly active enzyme system in this pathway, especially, cleavage enzymes of carbohydrates, $\alpha$-acetolactate forming enzyme, reductive enzyme requiring TPNH, and transaminase. A detailed study on the mechanism of this fermentation is now in progress.

\section{SUMMARY}

1. A screening test for L-valine producing bacteria was carried out, and it was recognized that in shake culture a rather large amount of $\mathrm{L}$ valine is practically produced as the sole amino acid in the broth from carbohydrates and nitrogen sources by some species of bacteria.

2. Two strains of newly isolated L-valine accumulating bacteria were studied according to the system described in BERGEY's manual, and named Aerobacter cloacae var sp. NISR-B-151 and Aerobacter aerogenes NISR-B-801, respectively.

3. L-Valine was isolated from the culture broth in the crystalline form and identified.

4. The high level of $\mathrm{L}$-valine production is attributed to the newly isolated Aerobacter bacteria, yielding as much as 0.2 mole from one mole of glucose.

\section{ACKNOWLEDGEMENTS}

The author wishes to express his thanks to Prof. Emeritus K. SAKAguchi, Prof. T. Asai, Prof. Y. Sumiki, and Assit. Prof. K. Aida, the Institute of Applied Microbiology, Univ. of Tokyo, for their kind guidance and valuable advice throughout this study. He is also very grateful to Director K. Mogi and Dr. M. Mogi for their encouragement and supportance throughout the course of this work. Indebts also are due to the Institute of Applied Microbiology, Univ. of Tokyo, for elementary analysis and infrared spectra measurements.

\section{REFERENCES}

(1) S. Kinoshita, S. Udaka, M. Shimono: J. Gen. Appl. Microbiol., 3, 193 (1957)

(2) S. Kinoshita, K. Nakayama and S. Kitada: J. Gen. Appl. Microbiol., 4, 128 (1958)

(3) K. Aida, T. Asai, T. KaJiwara and K. IIzUKa: J. Gen. Appl. Microbiol., 4, 200 (1958)

(4) T. AsaI, K. AIDA, K. Oishi: J. Ferm. Assoc. (Japan) 15. 1 (1957)

(5) S. Udaka, K. Tomizawa, S. Kinoshita: Lecture delivered on the meeting of Agricultural and Chemical Society in Japan, Oct. 25, 1958.

(6) S. M. PARTRIdge and R. C. Brimely: Biochem. J. (London) 48, 313 (1951). 
S. M. PARTRIDGe: Biochem. J. (London) 44, 521 (1949).

( 7 ) M. Strassman. A. J. Thomas, and S. Weinhouse: J. Am. Chem. Soc. 77, 1261 (1955)

(8) H. E. Umbarger and B. Brown: J. Biol. Chem., 233, 1156 (1958)

(9) R. P. Wagner, A. Bergquist, H. S. Forrest : J. Biol. Chem., 234, 99 (1959)

(10) D. Watt and L. O. Krampitz: Fed. Proc., 6, 301 (1947)

(11) D. Bonner: J. Biol. Chem., 166, 545 (1946)

(12) E. A. Adelberg and E. L. TAtum: Arch Biochem. 29, 235 (1950)

(13) E. J. ConwaY: "Microdiffusion Analysis and Volumetric Error' , Crosby Lockweed \& Son Ltd., London (1950)

(14) E. Juni: J. Biol, Chem., 195, 715 (1952). 